\title{
全国46地点を対象とした流域特性が \\ 洪水流量に及ぼす影響に関する研究 \\ INFLUENCE OF WATERSHED CHARACTERISTICS ON FLOOD DISCHARGE AT 46 WATER LEVEL STATIONS IN JAPAN: FINDINGS FROM FACTOR ANALYSIS AT DIFFERENT SCALES OF FLOOD
}

\author{
㛜島 怜 1 ・田中 亘 2 ・島谷幸宏 3 \\ Rei ITSUKUSHIMA, Wataru TANAKA and Yukihiro SHIMATANI \\ 1正会員 工博 九州大学 持続可能な社会のための決断科学センター（テ819-0395 福岡市西区元岡744） \\ 2非会員 工修 九州大学大学院 工学府（广819-0395 福岡市西区元岡744） \\ 3 フェロー会員 工博 九州大学大学院 工学研究院（三819-0395 福岡市西区元岡744）
}

\begin{abstract}
We examined relationship among specific discharge of flood and rainfall, geomorphology, land use and geology to reveal the influence of watershed characteristics on flood discharge. As a result of a correlation analysis, hourly rainfall depth was the most major factor to determine the flood discharge. Among the geomorphological factors, form factor and topographical gradient were major factors of increasing flood discharge. However, the effects of these factors differed by flood scale. In the land use factor, there was no clear relationship between broadleaf forest and flood discharge for each flood scale. Whereas, coniferous forest was factor to increase flood discharge at low frequency event.
\end{abstract}

Key Words : Flood discharge, Occurrence probability, Rainfall, Geomorphology, Land use, Geology

\section{1. はじめに}

流域からの洪水流出量は，基本的にはその流域に降っ た降水によって規制されるが，降水から流出の変換系と しての流域の特性によっても大きく異なる．流域の特性 寸なわち地形，地質，地質構造，地被条件，土地利用状 況等である ${ }^{1)}$.

森林植生は, 孔隙が多く保水性の高い森林土壌の形 成・維持を通じて洪水流を減少させ流出を遅延させる効 果が指摘されている2)。また，森林植生の違いによる流 出抑制効果の研究もみられ, 落葉広葉樹林の土壌の最終 浸透能および雨水貯留能は針葉樹人工林や人工草地に比 べて相対的に大きいことが指摘されている3 ${ }^{3}$. 一方，平 野らは，針葉樹林域と広葉樹林域の短期流出特性を調べ, 小規模降雨では落葉広葉樹林のほうが針葉樹人工林より も洪水緩和機能が高いと判断されるだろうが，大規模台 風イベント（総降水量 $100 \mathrm{~mm}$ 以上）では落葉広葉樹の洪 水緩和機能が針葉樹人工林よりも高いとは判断できない と指摘している4). また, 森林の流出抑制機能について, 総降雨量の増大とともに流出が顕著に大きくなることが 指摘されている5), の. 田村ら》は吉野川のスギ・ヒノキ人 工林流域と岩木川のブナ原生林流域の洪水低減機能を比
較し，主要樹種の違いと流出抑制機能が直結するもので ないことを明らかにしており，Iroumeら ${ }^{8}$ は樹齢が異な る植林地流域の洪水流量を比較し，両者の間に大きな差 異がないことを明らかにしている.

流域地質と河川流量の関係についての研究事例と して，低水流出指標及び年最大流量と地質の関係を 調べた虫明ら9の研究や, 九州の32河川の豊水量と渇 水量の比である流況係数と地質の関係を調べた岸原 ら占が挙げられる。 そのほか, 全国70の山地流域を対 象に流量と流域の年降水量, 地質, 傾斜, 植生との 関連を調べた志水ら ${ }^{10)}$ の研究，花崗岩地帯の河川の低 水時の流出特性を調べた寺本ら ${ }^{11)}$ の研究がある. また, Meijerink ${ }^{12)}$ は南部イタリアの半乾燥地帯を対象に, 大 規模な出水のピーク流量は岩質とは無関係であるこ とを明らかにした。

地形と河川流量の関係は河川地形学の分野で古くから 研究されている. 流量と流域面積の関係を調べた事例と して, 洪水ピーク流量が流域面積のべき乗に比例するこ とを明らかにしたHackら ${ }^{13}$ の研究，比流量が流域面積の 増加に伴い指数的に逢減することを示した花沢 ${ }^{14}$ の研究 が挙げられる．また，Carlston ${ }^{15}$ は北米の15河川について, 年平均最大流量は河床勾配や降水量と無関係の影響を受 
けず，水系密度と密接な関係があることを明らかとし， Stall ${ }^{16)}$ は米国のEmbarras川において15年間の観測期間 のうち出現頻度が $10 \%$ の規模の流量が河川次数と高い相 関関係にあることを示した。

これらの研究は流域特性のうち植生や地質など単一要 因に着目した研究や, 年最大流量といった特定の規模を 対象としているものが大部分である. しかし，洪水流量 に影響を及ぼす要因は複合的であり，かつ生起確率毎に 影響の程度は変化すると考えられる。

そこで, 本研究では, 洪水の規模毎にどのような流域 特性要因が洪水流量に影響するかを明らかにするため, 洪水流量に影響を及ぼす要因として, 降雨, 地形, 土地 利用及び地質に着目し, 生起確率毎の洪水流量とこれら の要因の関係を分析した.

\section{2. 方法}

\section{(1) 対象地点}

対象地点は流量観測が30年以上実施されている地点と した．また，ダムによる洪水調節の影響が少な地点を抽 出するため, 洪水調節を行うダムの集水面積が流域面積 の $10 \%$ 以上占める地点は対象外とした。対象地点の位 置を表-1に示す.

\section{（2）データの収集}

河川の洪水に影響を及ぼす要因として，降雨，地形， 土地利用及び地質を対象とした。これらの要因について 合計15種の指標項目を設定した（図-2）。以下に各指標 の整理方法について記す。

\section{a) 流量データ}

流量データは水文水質データベース (http://www1.river.go.jp/) の流況表における各年の最大 流量を使用した. 各地点の年最大流量標本を統計処理し, 生起確率 2 年, 10 年, 30 年, 50 年, 80 年, 100 年 (以下, $1 / 2 ， 1 / 10 ， 1 / 30 ， 1 / 50 ， 1 / 80$ 及び $1 / 100$ と表示）の流量を 算定した. 統計処理は，水文統計ユーティリティVer.1.5. を用い，13種の確率分布モデルのうちSLSCが最小とな る確率分布の確率水文量を採用した。

\section{b) 雨量データ}

雨量データは気象庁HPの過去データ検索 (http://www.jma.go.jp/jma/index.html）のうち，統計期間 が32年以上の観測点の年間日最大雨量及び時間最大雨量 を使用した。ティ一線分割によって対象流域の流域平均 雨量（日最大，時間最大）の標本を作成し，流量データ と同様の手法によって $1 / 2 ， 1 / 10 ， 1 / 30 ， 1 / 50 ， 1 / 80$ 及び 1/100の降雨量を算出した.

\section{c) 地形データ}

地形要因として, 主流路の勾配の逆数, 地形勾配, 形 状比及び円状率を設定した。主流路の勾配は対象地点に おける標高と主流路の源流標高の差を流路長で除したも
のを主流路の勾配と定義し, その逆数を対数值で示した ものを指標とした．形状比はHortonが提唱した流域の形 状を数值で表したもので流域面積を流路延長の2乗で除 した值であり，流域が方形ないし円形に近いほど1.0に 近づく指標である ${ }^{17)}$. 円状率は，流域と同面積の円の円 周を流域周囲長で除したものである ${ }^{18)}$ ，地形データは全 球高精度デジタル3D地困（ALOS World 3D-30m ${ }^{19)}$ ) を用 い, 地理情報システム (Geographic Information System: GIS，以下GISと記述）により計測した.

\section{d) 土地利用データ}

各流域の土地利用の構成割合を，環境省が実施した自 然環境保全基礎調査結果（2万 5 千分の 1 ）

(http://www.vegetation.biodic.go.jp/legend.html）から算出 した. 土地利用の分類は58種類の統一凡例（大区分）か ら，流出現象に及ぼす影響が異なると考えられる区分と して針葉樹林，広葉樹林，針広混交林，耕作地等及び市 街地等の5区分に再区分した. 尚, 火山性植生，水辺林， 低木群落等全地点で構成割合が5\%未満のものについて は対象外とした。

\section{e) 土地利用データ}

表層地質のデータは国土交通省国土情報課が公表して いる20万分の 1 表層地質図に基づいて，地質の生成過程 から, 火山岩類, 深成岩類, 変成岩類, 堆積岩類, 堆積

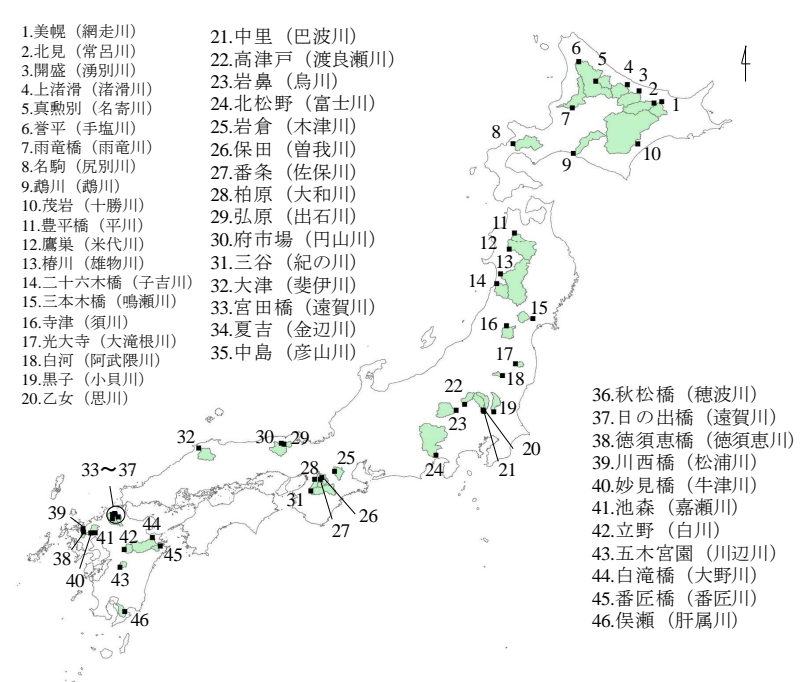

図-1 対象地点位置図

表-1 設定した降雨，地形，土地利用，地質要因

\begin{tabular}{|c|c|}
\hline \multirow{2}{*}{ 1.降雨要因 } & 1) 確率規模每の日雨量 \\
\hline & 2) 確率規模毎の時間雨量 \\
\hline \multirow{4}{*}{ 2. 地形要因 } & 3) 河道勾配の逆数 \\
\hline & 4) 地形勾配 \\
\hline & 5) 形状比 \\
\hline & 6) 円状率 \\
\hline \multirow{4}{*}{ 3.土地利用要因 } & 7) 広葉樹林の割合 \\
\hline & 8) 針葉樹林の割合 \\
\hline & 9) 耕作地等の面積 \\
\hline & 10)市街地等の割合 \\
\hline \multirow{5}{*}{ 4. 地質要因 } & 11) 火山岩類の割合 \\
\hline & 12) 深成岩類の割合 \\
\hline & 13) 変成岩類の割合 \\
\hline & 14) 堆積岩類の割合 \\
\hline & 15) 堆積物の割合 \\
\hline
\end{tabular}


物の5種類に区分した. GISによって流域毎の表層地質割 合を算出した.

\section{3）解析方法}

生起確率毎の洪水流量と降雨, 地形, 土地利用及び地 質要因との関連性を調べるため, 単相関分析を行った. 単相関分析には，Pearsonの積率相関係数を用いた．洪水 流量は降雨による影響を最も強く受けるため，地形，土 地利用及び地質要因と比流量の関係を調べる際には，標 準化比流量を用いた。 ここで，標準化比流量とは，洪水 流量を流量と同規模の生起確率雨量（時間雨量）で除し た值である.

次に, 生起確率每の洪水流量を目的変数に, 降雨, 地 形，土地利用及び地質の各要因を説明変数として重回帰 分析を行った. 変数選択の前段階として説明変数間の相 関係数を調へ，9)耕作地等と 15)堆積物，4)地形勾配と
15)堆積物及び4)地形勾配と9)耕作地等との間に強い正の 相関関係（r>0.70）がみられたことから，9)耕作地等と 15)堆積物を解析の対象外とした. 説明変数の選択は増 減法により行い，赤池情報量規準 (Akaike's Information Criterion: AIC) が最小值となる变数群を対象として重回 帰分析を行った.

\section{3. 結果及び考察}

\section{（1）生起確率毎の洪水流量及び降雨量}

表-2に統計処理によって算出した生起確率毎の洪水比 流量及び降雨量を示す．特徴を概略すると，いずれの生 起確率においても比流量が最も大きい地点は九州地方

(1/2流量, $1 / 50$ 流量, $1 / 80$ 流量, $1 / 100$ 流量 : 牛津川妙見 橋, $1 / 10$ 流量, $1 / 30$ 流量 : 番匠川番匠橋) , 最も小さい

表-2 生起確率毎の洪水流量及び降雨量

\begin{tabular}{|c|c|c|c|c|c|c|c|c|c|c|c|c|c|c|c|c|c|}
\hline \multirow{2}{*}{ No } & \multirow{2}{*}{ 水系名 } & \multirow{2}{*}{ 河川名 } & \multirow{2}{*}{ 観測所 } & \multicolumn{4}{|c|}{ 生起確率に対する比流量 } & \multicolumn{2}{|c|}{$\left(\mathrm{Q}^{3} / \mathrm{s} / \mathrm{km}^{2}\right)$} & \multirow{2}{*}{$\begin{array}{c}\begin{array}{c}\text { 確率分布 } \\
\text { モデル }\end{array} \\
\end{array}$} & \multicolumn{6}{|c|}{ 生起確率に対する時間雨量 $(\mathrm{mm} / \mathrm{h})$} & \multirow{2}{*}{$\begin{array}{c}\text { 確率分布 } \\
\text { モデル }\end{array}$} \\
\hline & & & & $1 / 2$ & $1 / 10$ & $1 / 30$ & $1 / 50$ & $1 / 80$ & $1 / 100$ & & $1 / 2$ & $1 / 10$ & $1 / 30$ & $1 / 50$ & $1 / 80$ & $1 / 100$ & \\
\hline 1 & 網走川 & 網走川 & 美幌 & 0.17 & 0.42 & 0.70 & 0.87 & 1.06 & 1.17 & LogP3 & 21.2 & 30.7 & 36.2 & 38.7 & 40.9 & 42.0 & Iwai \\
\hline 2 & 常呂川 & 常呂川 & 北見 & 0.18 & 0.46 & 0.65 & 0.74 & 0.82 & 0.85 & $\exp$ & 21.3 & 27.9 & 30.4 & 31.2 & 31.9 & 32.2 & $\log \mathrm{P} 3$ \\
\hline 3 & 湧別川 & 湧別川 & 開盛 & 0.24 & 0.61 & 0.87 & 0.99 & 1.10 & 1.15 & $\exp$ & 19.0 & 27.4 & 32.4 & 34.7 & 36.8 & 37.8 & Gumbel \\
\hline 4 & 渚滑川 & 渚滑川 & 上渚滑 & 0.32 & 0.78 & 1.09 & 1.23 & 1.23 & 1.43 & $\exp$ & 18.2 & 26.4 & 30.4 & 32.0 & 33.4 & 34.0 & LogP3 \\
\hline 5 & 天塩川 & 名寄川 & 真勲別 & 0.46 & 1.00 & 1.38 & 1.55 & 1.71 & 1.79 & $\exp$ & 19.5 & 29.5 & 36.4 & 39.7 & 43.0 & 44.6 & LogP3 \\
\hline 6 & 手塩川 & 手塩川 & 誉平 & 0.37 & 0.61 & 0.78 & 0.86 & 0.94 & 0.98 & SqrtEt & 21.3 & 28.9 & 32.9 & 34.7 & 36.3 & 37.0 & Iwai \\
\hline 7 & 石狩川 & 雨竜川 & 雨竜橋 & 0.49 & 0.90 & 1.29 & 1.52 & 1.76 & 1.89 & $\exp$ & 21.6 & 31.1 & 35.7 & 37.5 & 39.1 & 39.8 & Gev \\
\hline 8 & 尻別川 & 尻別川 & 名駒 & 0.42 & 0.73 & 0.94 & 1.04 & 1.14 & 1.18 & $\log \mathrm{P} 3$ & 20.4 & 29.7 & 35.3 & 37.8 & 40.1 & 41.2 & Iwai \\
\hline 9 & 鵡川 & 武鳥川 & 武鳥川 & 0.58 & 1.54 & 2.19 & 2.50 & 2.78 & 2.91 & $\exp$ & 23.5 & 33.0 & 37.8 & 39.8 & 41.6 & 42.3 & Gev \\
\hline 10 & 十勝川 & 十勝川 & 茂岩 & 0.25 & 0.53 & 0.75 & 0.87 & 0.98 & 1.04 & $\log \mathrm{P} 3$ & 20.1 & 25.4 & 27.4 & 28.2 & 28.8 & 29.1 & LogP3 \\
\hline 11 & 岩木川 & 平川 & 豊平橋 & 0.92 & 1.66 & 2.18 & 2.44 & 2.70 & 2.82 & Gev & 24.1 & 40.5 & 52.5 & 58.7 & 64.7 & 67.6 & Gev \\
\hline 12 & 米代川 & 米代川 & 鷹巣 & 0.62 & 1.11 & 1.40 & 1.67 & 1.65 & 1.71 & Gumbel & 26.5 & 38.3 & 45.9 & 49.4 & 52.8 & 54.4 & $\log \mathrm{P} 3$ \\
\hline 13 & 雄物川 & 雄物川 & 椿川 & 0.50 & 0.72 & 0.82 & 0.86 & 0.90 & 0.91 & LogP3 & 30.8 & 38.8 & 42.5 & 44.0 & 45.3 & 45.9 & $\log \mathrm{P} 3$ \\
\hline 14 & 子吉川 & 子吉川 & 二十六木橋 & 0.86 & 1.40 & 1.73 & 1.88 & 2.02 & 2.08 & Iwai & 27.7 & 39.5 & 46.6 & 49.8 & 52.8 & 54.2 & Iwai \\
\hline 15 & 鳴瀬川 & 鳴瀬川 & 三本木橋 & 1.10 & 2.39 & 3.33 & 3.80 & 4.26 & 4.48 & LN2LM & 26.3 & 37.8 & 44.7 & 47.8 & 50.7 & 52.0 & Gumbel \\
\hline 16 & 最上川 & 須川 & 寺津 & 0.52 & 1.21 & 1.75 & 2.03 & 2.30 & 2.44 & Iwai & 25.9 & 39.3 & 47.2 & 50.8 & 54.0 & 55.6 & Iwai \\
\hline 17 & 阿武隈川 & 大滝根川 & 光大寺 & 0.55 & 1.14 & 1.54 & 1.73 & 1.92 & 2.01 & Iwai & 27.9 & 40.9 & 47.9 & 50.8 & 53.4 & 54.6 & Gev \\
\hline 18 & 阿武隈川 & 阿武隈川 & 白河 & 0.77 & 2.07 & 3.09 & 3.62 & 4.13 & 4.39 & SqrtEt & 34.2 & 53.2 & 65.8 & 71.9 & 77.7 & 80.5 & $\log \mathrm{P} 3$ \\
\hline 19 & 利根川 & 小貝川 & 黒子 & 0.68 & 1.27 & 1.70 & 1.92 & 2.13 & 2.23 & SqrtEt & 35.8 & 50.7 & 58.1 & 61.2 & 63.9 & 65.1 & Gev \\
\hline 20 & 利根川 & 思川 & 乙女 & 1.29 & 2.58 & 3.36 & 3.71 & 4.04 & 4.19 & Gumbel & 42.5 & 59.6 & 70.1 & 74.9 & 79.3 & 81.4 & Gev \\
\hline 21 & 利根川 & 巴波川 & 中里 & 0.72 & 1.42 & 1.87 & 2.08 & 2.28 & 2.37 & Gev & 41.5 & 55.0 & 62.5 & 65.7 & 68.6 & 69.9 & Gev \\
\hline 22 & 利根川 & 渡良瀬川 & 高津戸 & 1.32 & 3.40 & 4.58 & 5.07 & 5.49 & 5.68 & $\log \mathrm{P} 3$ & 39.6 & 51.8 & 57.6 & 60.0 & 62.0 & 63.0 & Iwai \\
\hline 23 & 利根川 & 烏川 & 岩鼻 & 1.11 & 2.71 & 3.60 & 3.98 & 4.31 & 4.45 & Gev & 38.5 & 54.2 & 61.7 & 64.7 & 67.4 & 68.6 & $\log \mathrm{P} 3$ \\
\hline 24 & 富士川 & 富士川 & 北松野 & 1.13 & 2.55 & 3.37 & 3.73 & 4.05 & 4.20 & Iwai & 32.0 & 40.3 & 43.5 & 44.6 & 45.6 & 46.0 & $\log \mathrm{P} 3$ \\
\hline 25 & 淀川 & 木津川 & 岩倉 & 1.44 & 2.86 & 3.86 & 4.35 & 4.82 & 5.05 & Iwai & 35.3 & 50.4 & 58.3 & 61.8 & 64.9 & 66.3 & Iwai \\
\hline 26 & 大和川 & 曽我川 & 保田 & 1.53 & 2.55 & 3.16 & 3.44 & 3.69 & 3.82 & Gumbel & 32.2 & 43.9 & 50.2 & 52.9 & 55.2 & 56.3 & Gev \\
\hline 27 & 大和川 & 佐保川 & 番条 & 1.72 & 2.93 & 3.72 & 4.10 & 4.46 & 4.63 & Iwai & 34.8 & 54.4 & 69.5 & 77.4 & 85.2 & 89.1 & $\mathrm{Gev}$ \\
\hline 28 & 大和川 & 大和川 & 柏原 & 1.09 & 1.73 & 2.04 & 2.17 & 2.27 & 2.32 & Gev & 34.2 & 42.3 & 46.0 & 47.4 & 48.7 & 49.2 & LogP3 \\
\hline 29 & 円山川 & 出石川 & 弘原 & 1.01 & 3.34 & 4.93 & 5.67 & 6.35 & 6.67 & $\exp$ & 32.3 & 42.9 & 47.5 & 49.2 & 50.7 & 51.3 & Gev \\
\hline 30 & 円山川 & 円山川 & 府市場 & 1.34 & 2.95 & 4.13 & 4.73 & 5.30 & 5.58 & Iwai & 34.5 & 45.9 & 50.6 & 52.4 & 53.8 & 54.4 & Gev \\
\hline 31 & 紀の川 & 紀の川 & 三谷 & 1.53 & 3.73 & 5.43 & 6.30 & 7.14 & 7.56 & SqrtEt & 39.0 & 47.3 & 50.6 & 51.8 & 52.8 & 53.3 & LogP3 \\
\hline 32 & 斐伊川 & 斐伊川 & 大津 & 0.78 & 1.64 & 2.30 & 2.65 & 3.00 & 3.17 & Gev & 33.7 & 47.2 & 55.8 & 59.8 & 63.5 & 65.2 & $\mathrm{Gev}$ \\
\hline 33 & 遠賀川 & 犬鳴川 & 宮田橋 & 1.76 & 3.63 & 4.99 & 5.67 & 6.33 & 6.64 & Iwai & 44.6 & 64.5 & 76.4 & 81.9 & 86.9 & 89.2 & Gumbel \\
\hline 34 & 遠賀川 & 金辺川 & 夏吉 & 3.51 & 6.28 & 7.64 & 8.21 & 8.70 & 8.91 & LogP3 & 43.1 & 64.3 & 77.3 & 83.3 & 88.8 & 91.5 & $\log \mathrm{P} 3$ \\
\hline 35 & 遠賀川 & 彦山川 & 中島 & 1.55 & 3.08 & 4.17 & 4.73 & 5.26 & 5.53 & $\mathrm{Gev}$ & 46.7 & 67.4 & 79.8 & 85.5 & 90.7 & 93.1 & Gumbel \\
\hline 36 & 遠賀川 & 穂波川 & 秋松橋 & 3.17 & 6.24 & 8.20 & 9.12 & 9.97 & 10.38 & $\log \mathrm{P} 3$ & 48.0 & 69.6 & 82.5 & 88.5 & 93.9 & 96.5 & $\log \mathrm{P} 3$ \\
\hline 37 & 遠賀川 & 遠賀川 & 日の出橋 & 1.75 & 3.45 & 4.51 & 5.00 & 5.45 & 5.66 & Gumbel & 47.7 & 65.8 & 75.8 & 80.3 & 84.2 & 86.0 & Gev \\
\hline 38 & 松浦川 & 徳須恵川 & 徳須恵橋 & 3.37 & 6.41 & 8.25 & 9.08 & 9.85 & 10.21 & Gumbel & 48.1 & 75.4 & 95.0 & 104.8 & 114.3 & 119.0 & Gev \\
\hline 39 & 松浦川 & 松浦川 & 川西橋 & 3.60 & 5.89 & 7.27 & 7.89 & 8.47 & 8.74 & Gumbel & 49.2 & 70.3 & 83.0 & 88.8 & 94.1 & 96.6 & Gumbel \\
\hline 40 & 六角川 & 牛津川 & 妙見橋 & 3.68 & 7.21 & 9.62 & 10.79 & 11.91 & 12.45 & Gev & 44.4 & 67.3 & 80.0 & 85.6 & 90.6 & 93.0 & Iwai \\
\hline 41 & 嘉瀬川 & 嘉瀬川 & 池森 & 1.83 & 3.85 & 5.83 & 7.00 & 8.25 & 8.91 & $\log \mathrm{P} 3$ & 44.1 & 67.6 & 80.1 & 85.4 & 90.2 & 92.5 & $\log \mathrm{P} 3$ \\
\hline 42 & 白川 & 白川 & 立野 & 2.07 & 3.38 & 4.17 & 4.53 & 4.85 & 5.01 & Gumbel & 46.3 & 68.7 & 83.1 & 89.8 & 96.2 & 99.3 & $\log \mathrm{P} 3$ \\
\hline 43 & 球磨川 & 川辺川 & 五木宮園 & 1.79 & 4.38 & 6.46 & 7.53 & 8.59 & 9.12 & Iwai & 44.0 & 63.9 & 75.9 & 81.4 & 86.4 & 88.8 & Gumbel \\
\hline 44 & 大野川 & 大野川 & 白滝橋 & 1.97 & 4.81 & 6.84 & 7.83 & 8.76 & 9.21 & LogP3 & 39.2 & 54.9 & 64.4 & 68.8 & 72.7 & 74.6 & Gumbel \\
\hline 45 & 番匠川 & 番匠川 & 番匠橋 & 3.51 & 9.01 & 10.23 & 10.51 & 10.69 & 10.75 & LogP3 & 42.8 & 62.2 & 73.0 & 77.8 & 82.2 & 84.2 & Iwai \\
\hline 46 & 肝属川 & 肝属川 & 俣瀬 & 1.78 & 3.11 & 3.96 & 4.36 & 4.74 & 4.92 & Iwai & 52.1 & 66.6 & 73.7 & 76.7 & 79.3 & 80.6 & Iwai \\
\hline
\end{tabular}


地点は北海道地方（1/2流量， $1 / 10$ 流量 : 網走川美幌, $1 / 30$ 流量, $1 / 50$ 流量, $1 / 80$ 流量, $1 / 100$ 流量 : 常呂川北 見）に属している. 時間雨量についても同様の傾向が みられた。降雨の地域的な分布によって生起確率毎の 比流量が異なることから, 流域特性と洪水比流量の関 係を調べる際に，降雨による影響を除く必要があるた め，比流量を降雨で除して分析を行った。

\section{(2) 単相関分析}

以下に降雨，地形，土地利用及び地質と生起確率毎 の比流量の関係について説明する. 尚, 各要因とも, $1 / 80$ 流量と $1 / 100$ 流量で類似の傾向がみられたため, こ こでは，1/2，1/10，1/30，1/50，及び1/100の流量を対象 とする.

\section{a) 降雨と比流量の関係}

図-2に日雨量と比流量の関係を，図-3に時間雨量と 比流量の関係を示す.いずれも全ての確率規模におい て高い相関がみられたが，時間雨量の方がより強い相 関関係を示した. 洪水のピーク流量を形成する降雨が 洪水到達時間程度であることから，対象とした流域で は洪水比流量は1時間程度の降雨の影響を強く受けてい ることが明らかとなった。

\section{b) 地形要因と標準化比流量の関係}

4種類の地形要因のうち, 標準化比流量との相関関係 で特徵的な傾向がみられた, 地形勾配, 形状比及び河 道勾配の逆数を取り上げ説明する.

標準化比流量と地形勾配の関係は, 確率規模の増加 とともに正の相関関係が強まり，1/2流量を除き $5 \%$ 水準 で有意であった（図-4）。小規模出水では，浸透によ る初期損失が洪水に及ぼす影響が大きく, 浸透現象, 流出現象に関連する土地利用や地質及び地質の影響が 大きく地形勾配の影響は小さいものと考えられる。一 方, 出水規模の増大に伴い, 土地被覆や地質による浸 透が洪水流量に及ぼす影響が弱まり，地形勾配の影響 が支配的になると考えらえる.

標準化比流量と形状比の関係は確率規模の増加とと もに正の相関関係が減少し，1/2流量の場合のみ $5 \%$ 水準 で有意な関係が認められた（図-5）。青木ら ${ }^{20}$ は，同一 規模の出水を対象に流域形状が異なることで洪水ピー ク流量が変化することを明らかにしているが，本分析 結果から, 洪水規模によってその影響が異なることが 明らかとなった。 小規模出水では，流域内の降雨量の 差異が少なく，ピーク流量が重複する傾向にあるため， 円形に近い流域ほど支川合流によって流量が増幅され 比流量増加すると考えられる. しかし, 大規模な出水 では，流域内の降雨量に差が生じ，特定の流域からの 出水の影響が卓越するなど, 流域の形状の違いが流量 に及ぼす影響が小さいものと考えられる.

標準化比流量と主流路の河道勾配の逆数はいずれの 確率規模でも, 勾配が急であるほど標準化比流量が大

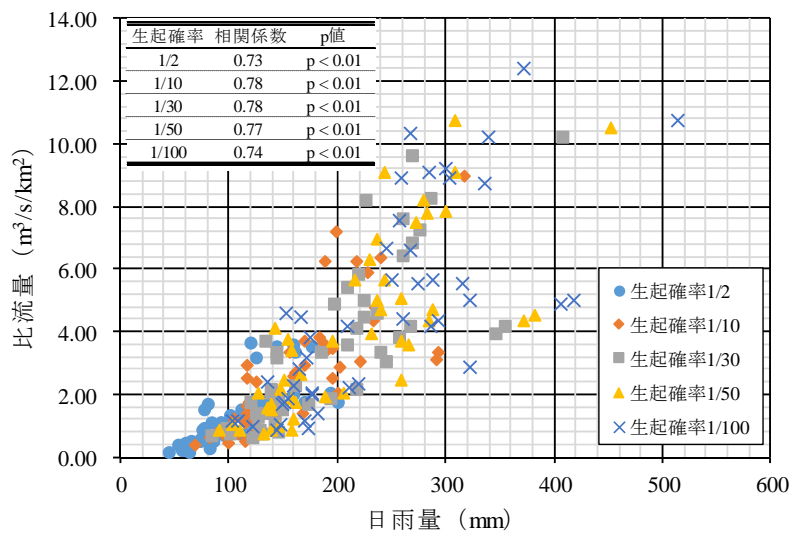

図-2日雨量と比流量の関係

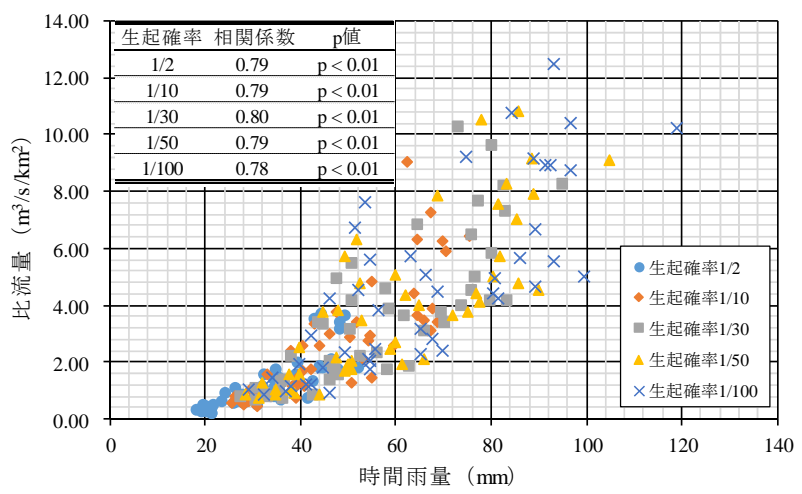

図-3＼cjkstart時間雨量と比流量の関係

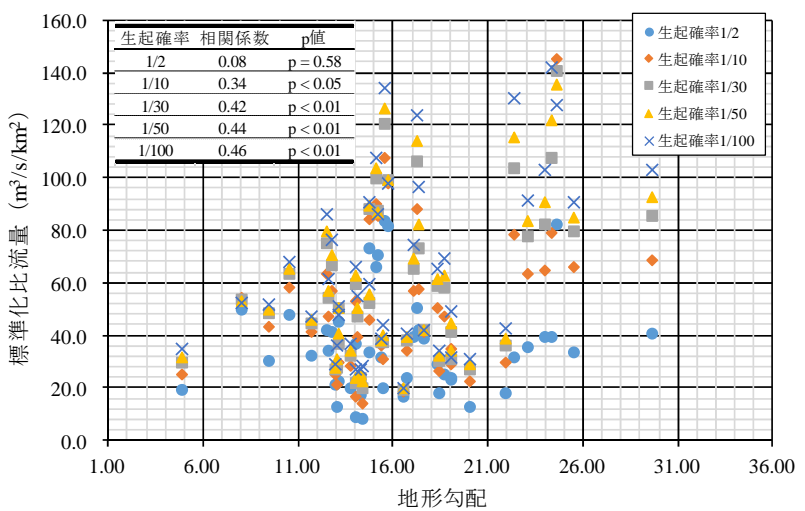

図-4＼cjkstart地形勾配と標準化比流量の関係

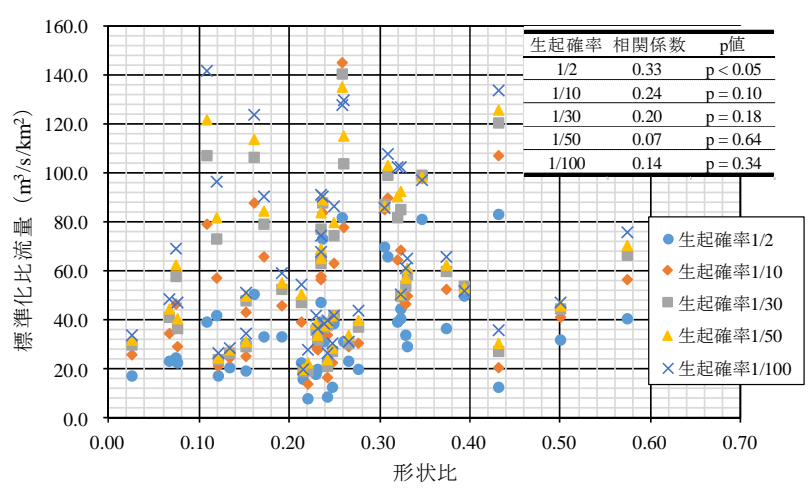

図-5＼cjkstart形状比と標準化比流量の関係 


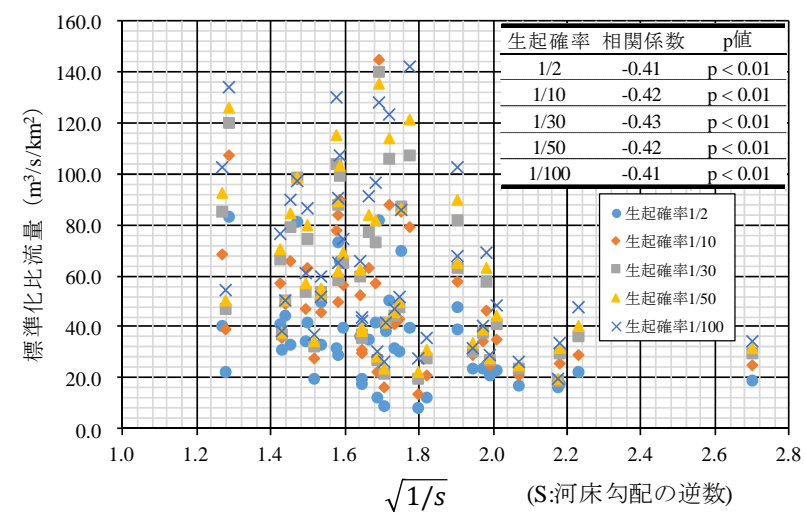

図-6 河道勾配の逆数と標準化比流量の関係

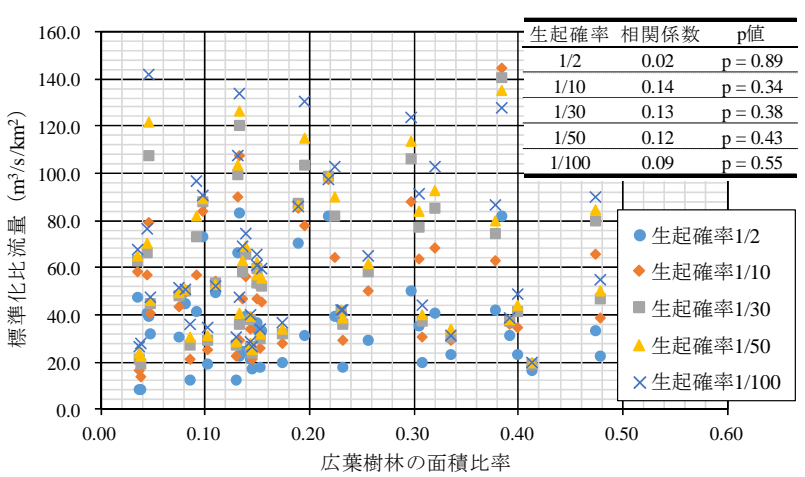

図-7＼cjkstart広葉樹林と標準化比流量の関係

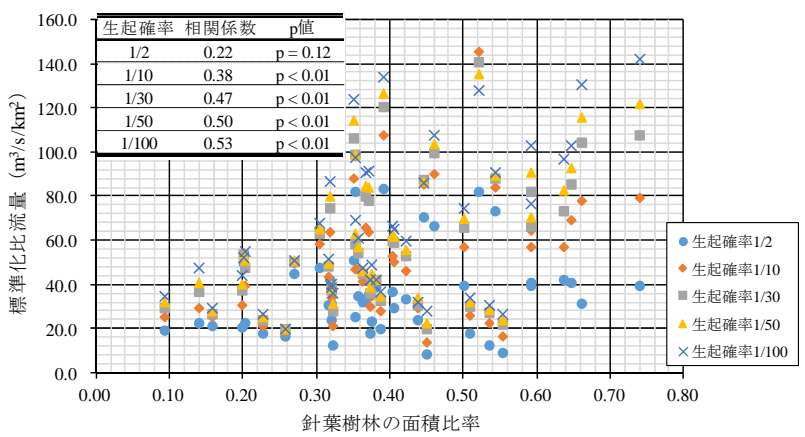

図-8＼cjkstart針葉樹林と標準化比流量の関係

表-3 重回帰分析結果

\begin{tabular}{|c|c|c|c|c|c|c|}
\hline 生起確率 & $\begin{array}{c}\text { 時間雨量 } \\
(※)\end{array}$ & 形状比 & 地形勾配 & 針広混交林 & R-squared & $\begin{array}{l}\text { Adjusted } \\
\text { R-squared }\end{array}$ \\
\hline \multirow{2}{*}{2} & 0.7559 & 0.1826 & & & 0.6546 & 0.6385 \\
\hline & $* * *$ & . & & & $* * *$ & \\
\hline \multirow{2}{*}{10} & 0.8668 & 0.1838 & 0.2811 & 0.1571 & 0.7247 & 0.6978 \\
\hline & $* * *$ & . & $* *$ & & $* * *$ & \\
\hline \multirow{2}{*}{30} & 0.7856 & 0.1367 & 0.3185 & & 0.7459 & 0.7277 \\
\hline & $* * *$ & - & $* * *$ & & **** & \\
\hline \multirow{2}{*}{50} & 0.7875 & 0.1285 & 0.3372 & & 0.7481 & 0.7301 \\
\hline & $* * *$ & & *** & & **** & \\
\hline \multirow{2}{*}{80} & 0.7849 & 0.1186 & 0.3477 & & 0.7392 & 0.7206 \\
\hline & $* * *$ & & $* * *$ & & $* * *$ & \\
\hline \multirow{2}{*}{100} & 0.7816 & 0.1145 & 0.3544 & & 0.733 & 0.7139 \\
\hline & $* * *$ & & $* * *$ & & $* * *$ & \\
\hline
\end{tabular}

きく，その関係は対数関係で説明され，確率規模毎で 大きな変化はなく $5 \%$ 水準で有意であった（図-6）.

\section{c) 土地利用要因と標準化比流量の関係}

5 種類の土地利用要因のうち森林に注目し, 標準比流 量との関係について記述する. 図-7に広葉樹林と標準 化比流量の関係を，図-8に針葉樹林と標準化比流量の 関係を示す．小規模出水では針葉樹林と標準化比流量 との間に明瞭な関係はみられなかったが，大規模出水 では流域に占める割合が大きいほど標準化比流量が増 加する結果となった。この関係は1/2流量を除いて $5 \%$ 水 準で有意であった，一方，広葉樹林はいずれの生起確 率において標準化比流量との明瞭な関係はみられな かった，森林は一般に洪水調節機能を有しており，針 葉樹林と広葉樹林で流出抑制効果が異なることが指摘 されている3). 上記の結果は両者の流出抑制機構の違い を示唆するものであるが，本分析結果から森林が有す る流出抑制効果を検証することはできなかった。 これ は, 本研究が比較的大きなスケールの流域面積を対象 としており，森林の流出抑制機能を検証するうえで適 切な規模でない可能性があること，森林の流出抑制効 果は林床の状況，間伐といった維持管理状況が影響し ており，単純な樹種のみの分類では検証が困難である ことが原因として考えられる.

\section{d) 地質要因之標準化比流量の関係}

5\%水準で標淮化比流量と有意な相関関係を持つ地質 要因はなかった. しかし, 火山岩類, 堆積岩類及び堆 積物はいずれの確率規模においても負の相関係数と なっており，洪水流量を減じさせる要因となっている 可能性がある. 虫明ら ${ }^{9} は$, 全国124河川の流況と地質 の関係を調べ，年最大流量は第四紀火山岩類流域が際 立って小さいことを明らかにしている，本研究では大 規模出水のピーク流量のみを対象としており，地質の 違いによる浸透能の差異が及ぼす影響が明瞭に現れな かったと考えられる. しかし，大規模出水においても 地質の差異がピーク時間の遅滞やピーク後の流量聥減 過程一影響を及ぼしている可能性は高く，洪水流量と 地質の関係を明らかにするためには，ピーク流量以外 の洪水特性と地質の関係を調べる必要がある。

\section{（3）重回帰分析}

表-3に生起確率毎の比流量を目的変数に, 降雨, 地 形，土地利用及び地質要因を説明変数として重回帰分 析を行った結果を示す. 表中に記載した数字が各説明 変数の標準化回帰係数を示しており，その絶対值の大 小が目的変数に対する寄与の程度を示している. 各生 起確率の自由度調整済み決定係数は0.64〜0.73であり， モデルは適合している.

洪水流量に最も影響を与える要因は降雨であり，い ずれの生起確率でも高い標準化回帰係数を示した．地 形要因として, 形状比と地形勾配が説明変数として選 
択されているが, 寄与の程度は生起確率毎で異なる. 高頻度の出水では形状比の寄与が大きく, 低頻度の出 水では地形勾配の寄与が大きくなることがわかる。こ の傾向は単相関分析の結果と同様である.

重回帰分析の結果, 本研究で対象とした大規模な出 水では, 土地利用や地質といった浸透現象に大きな影 響を及ぼす要因はピーク流量の多寡への寄与は小さく， 雨量と地形要因の影響が強いことが明らかとなった。

\section{4. 結論}

本研究は, 洪水流量と降雨, 地形, 土地利用及び地 質要因の関係を明らかにするため, 過去の流量データ から生起確率毎の洪水流量を算出し各要因との関係を 調べたものである. 確率規模毎に流域特性值との関係 を調べることで, 洪水流量に影響を与える要因を洪水 規模毎に特定することができた.また, 流量を雨量に よって標準化することで, 洪水流量と流域特性の関係 を地域間で比較することが可能となった，特に，既往 研究において統一した見解がみられない樹林種別の洪 水緩和機能については, 確率規模毎に洪水流量との関 係を調べることで, 針葉樹林が大規模出水の増加要因 として特定された. 得られた知見を以下に要約する.

(1)いずれの生起確率においても洪水比流量と降雨量の 相関は強く, なかでも時間雨量の相関が最も強かった. (2)地形要因は降雨に次いで洪水流量に影響を及ぼす要 因であり, 影響の程度は規模によって異なることが明 らかとなった. 形状比は低規模出水時に洪水流量を増 加させる要因であるが, 出水規模が増大寸るとその影 響は弱まる. 一方, 地形勾配は頻度の低い出水時に洪 水流量を増加させる要因であることが明らかとなった． (3)比較的規模の大きな出水を対象とした本研究では, 森林の流出抑制機能は確認されなかった。 しかし, 広 葉樹林と針葉樹林では，洪水流量に及ぼす影響が異な ることが示唆された.

(4)地質要因と洪水流量に有意な相関関係は確認されな かったが, 火山岩類, 堆積岩類は洪水流量を減少じさ せる要因となっている可能性がある.

\section{参考文献}

1) 岸原信義, 田中洋二 : 流況係数と流域の地形・地質との関 連について, 日本林学会誌, Vol.57, No.8, pp.245-254, 1975.

2) 真板英一, 鈴木雅一: 森林植生の伐採が山地小流域の流況 曲線に与える影響一流況の流域間変動に対寸る植生要因の 大きさの検討一, 日本林学会誌, Vol.90, No.1, pp.36-45, 2008.

3) 村井宏 : 広葉樹林地, 針葉樹林地および草生地の水文特性の 比較, 水利科学, Vol.37, No.2, pp.1-40, 1993.

4) 平野智章, 寺嶋智巳, 中村智博, 境優, 青木文聡, 名波明
菜 : 針葉樹林流域と広葉樹林流域の短期流出特性の違い一 降雨イベントの規模が森林流域の水流発生機構に及ぼす影 響一, 水文・水資源学会誌, Vol.22, No.1, pp.24-39, 2009.

5) Tani, M.: Runoff generation processes estimated from hydrological observations on a steep forested hillslope with a thin soil layer, Journal of Hydrology, Vol.200, pp.84-109, 1997.

6) 地頭薗隆, 下川悦郎, 迫正敏, 寺本行芳 : 鹿児島県出水市 針原流域の水文地形的特徵と深層崩壊, 砂防学会誌, Vol.56, pp.15-26, 2003.

7) 田村隆雄, 端野道夫, 穴水秀樹, 荒木隆夫 : 吉野川池田ダ 么上流の森林流域の洪水低減機能に関寸る定量的評価, 水 工学論文集, 第52巻, pp.379-384, 2008.

8) Iroume, A, Mayen, O. and Huber, A.: Runoff and peak flow responses to timber harvest and forest age in southern Chile, Hydrological processes, Vol.20, No.1, pp.37-50, 2006.

9) 虫明功臣, 高橋裕, 安藤義久 : 日本の山地河川の流況に及 ぼす流域の地質の効果, 土木学会論文報告集, 第309号, pp.51-62, 1981.

10) 志水俊夫 : 日本における山地河川の流出特性, 水利科学, Vol.48, No.6, pp.6-17, 1996.

11) 寺本行芳, 下川悦郎, 地頭園隆, 馬込まり子 : 鹿児島県北 西部の花崗岩流域における低水時の流出特性, 鹿児島大学 農学部演習林研究報告, Vol.33, pp.1-8, 2005.

12) Meijerink, A. M. J.: Estimates of peak runoff from hilly terrain with varied lithology, Journal of Hydrology, Vol.77, pp.227-236, 1985.

13) Hack, J. T.: Studies of longitudinal stream profiles in Virginia and Maryland, USGS professional paper, Vol.294, chapter B, pp.45-97, 1957.

14) 花沢正男 : 本邦河川の流出量分布について, 電力気象連絡 会彙報, Vol.11, No.2, pp.91-102, 1960.

15) Carlston, C. W.: Drainage density and streamflow, USGS professional paper, Vol.422, chapter C, pp.1-8, 1957.

16) Stall, J. B., and Fok, Y. S.: Discharge as related to stream system morphology, in Symposium on River Morphology, International Association of Science and Hydrology, Bern, pp.224-235, 1967.

17) Horton, R. E.: Drainage Basin Characteristic, Transactions, American Geophysical Union, Vol.13, Issue 1, pp. 350-361, 1932.

18) Miller, V. C.: A quantitative geomorphic study of drainage basin characteristics in the Clinch mountain area, Virginia and Tennessee, Journal of Geology, Vol.65, no.1, pp.30, 1953.

19) Tadano, T., Ishida, H., Oda, F., Naito, S., Minakawa, K., and Iwamoto, H.: Precise Global DEM Generation by ALOS PRISM, ISPRS Annals of the Photogrammetry, Remote Sensing and Spatial Information Science, Vol. II -4, pp.71-76, 2004.

20) 青木慶, 岡部真人, 山田正 : 流域の地形特性が流量八イド ログラフの形成に与える影響, 水文・水資源学会研究発 表会要旨集, 24, pp.113-113, 2011.

(2015. 9. 30受付) 